\title{
REKSADANA SYARIAH DAN KONVENSIONAL DI INDONESIA
}

\author{
NURSETO ADHI 1 \\ DEWI PRATIWI AJI ${ }^{2}$ \\ WINARNI $^{3}$ \\ Politeknik Negeri Semarang ${ }^{123}$ \\ nurseto.adhi@polines.ac.id ${ }^{1}$ \\ dewiaji04@gmail.com² \\ winarni@polines.ac.id ${ }^{3}$
}

\begin{abstract}
This study aims to test the difference between the conventional mutual fund and the sharia mutual fund on performances and risk. The development of mutual fund products is based on 2 (two) categories, conventional mutual funds, and sharia mutual funds (www.ojk.go.id). Based on data from the Data Center and Statistics of Islamic Mutual Funds, the performance of Islamic mutual funds is still underperformed compared to conventional mutual funds. Therefore, testing the performance of Islamic mutual funds by testing the performance of conventional mutual funds has not been widely tested. Secondary data was used in this study with all 1425 mutual funds from 2012-2017 on the Indonesia Stock Exchange was used as the population in this study is. The purposive sampling technique determines the sample in this study. The sample used in this study was Conventional and Shariah mutual fund in Indonesia Stock Exchange (IDX) with six products each. This hypothesis test used Differential Test tools with data analysis techniques using Paired sample t-test analysis using SPSS 25. In this study, we found that there was a significant difference between the return on conventional mutual funds and Syariah mutual funds. While the risk, Sharpe method, Treynor method, and Jensen method have not significant difference between conventional mutual funds and Syariah mutual funds.
\end{abstract}

Keywords: Performance, Conventional Mutual Funds, Shariah Mutual Funds, Return, Risk

\begin{abstract}
Abstrak: Penelitian ini bertujuan untuk menguji perbedaan reksadana konvensional dan reksadana syariah dalam kinerja dan risikonya. Perkembangan produk reksadana didasarkan dalam 2 (dua) kategori yaitu reksadana konvensional dan reksadana syariah (www.ojk.go.id). Berdasarkan data dari Pusat Data dan Statistik menunjukkan bahwa Reksadana Syariah underperformed dibandingkan dengan reksadana konvensional. Oleh karena itu, Pengujian kinerja reksadana syariah dengan pengujian kinerja reksadana konvensional belum secara luas diuji. Penelitian ini menggunakan data sekunder dengan populasi yang digunakan dalam penelitian adalah seluruh reksadana yang ada di Bursa Efek Indonesia yang berjumlah 1425 reksadana. Sampel yang digunakan dalam penelitian ini adalah reksadana konvensional dan syariah di Bursa Efek Indonesia yang masing-masing berjumlah 6 (enam) produk. Pengujian hipotesis dengan menggunakan alat Uji Beda dengan teknik analisis data menggunakan analisis Paired sampel t-test. Hasil uji beda dari penelitian ini menunjukan bahwa terdpaat perbedaan yang signifikan antara return reksadana konvensional dan reksadana syariah. Sedangkan risiko, metode Sharpe, metode Treynor dan metode Jensen tidak mempunyai perbedaan signifikan antara reksadana konvensional dan reksadana syariah.
\end{abstract}

Kata kunci: Kinerja, Reksadana Konvensional, Reksadana Syariah, Return, Risiko

\section{PENDAHULUAN}

Reksadana merupakan salah satu instrumen derivatif. Undang-undang pasar modal No 8 Tahun 1995 pasal 1 ayat 2 menjelaskan bahwa reksadana merupakan sarana yang digunakan untuk menghimpun dana masyarakat pemodal yang kemudian diinvestasikan oleh manajer investasi pada portofolio efek. Hadi (2013:132) menjelaskan bahwa dengan adanya dana yang besar di reksadana dapat dilakukan diversifikasi investasi yang besar sehingga risiko yang dihadapi akan semakin kecil. 
Perkembangan produk reksadana didasarkan dalam 2 (dua) kategori yaitu reksadana konvensional dan reksadana syariah (www.ojk.go.id). Reksadana konvensional adalah reksadana yang tidak berlandaskan prinsip syariah, didalamnya perusahaan yang ditawarkan juga tidak berbasis syariat Islam. Sedangkan Reksadana Syariah adalah reksadana yang beroperasi menurut ketentuan dan prinsip syariah Islam, baik dalam akad antara Manajer Investasi (MI) dengan investor maupun emiten (Lestari, 2015). Pengelompokkan reksadana menjadi dua kategori ini disebabkan karena mayoritas penduduk Indonesia beragama islam, sehingga cukup banyak investor di Indonesia yang sangat mempertimbangkan syariat Islam.

Bagi para investor yang melakukan investasi dengan pertimbangan nilai-nilai syariah, pasti tidak akan melihat kinerja reksadana konvensional untuk investasinya dan akan lebih memilih reksadana syariah. Sedangkan untuk investor yang hanya mempertimbangkan mengenai kinerja reksadana, akan melihat return antara reksadana konvensional dengan reksadana syariah (Syafrida et al, 2014). Hal tersebut akan menjadi masalah karena reksandana Syariah cenderung baru di Indonesia sehingga Nilai Aktiva Bersih (NAB) reksadana syariah akan lebih kecil dibandingkan dengan NAB reksadana konvensional. Perbandingan antara reksadana konvensional dan syariah terlihat pada Tabel 1.

Tabel 1. Perbandingan Reksadana Konvensional dengan Reksadana Syariah

\begin{tabular}{|c|c|c|c|c|c|c|c|c|}
\hline \multirow[t]{2}{*}{ Tahun } & \multicolumn{2}{|c|}{$\begin{array}{l}\text { Perbandingan Jumlah } \\
\text { Reksadana Beredar } \\
\text { (dalam unit reksadana) }\end{array}$} & \multirow{2}{*}{$\begin{array}{c}\text { Total } \\
\text { Reksadana } \\
\text { (dalam unit) }\end{array}$} & \multirow[t]{2}{*}{$\begin{array}{l}\text { Prosentase } \\
\text { Reksadana }\end{array}$} & \multicolumn{2}{|c|}{$\begin{array}{c}\text { Perbandingan NAB ( dalam } \\
\text { Milyar Rupiah) }\end{array}$} & \multirow[t]{2}{*}{$\begin{array}{l}\text { Total } \\
\text { NAB }\end{array}$} & \multirow[t]{2}{*}{$\begin{array}{c}\text { Prosentase } \\
\text { NAB }\end{array}$} \\
\hline & Konvensional & Syariah & & & Konvensional & Syariah & & \\
\hline 2012 & 696 & 58 & 754 & $7,69 \%$ & $204.541,97$ & $8.050,07$ & $212.592,04$ & $3,79 \%$ \\
\hline 2013 & 758 & 65 & 823 & $7,90 \%$ & $183.112,33$ & $9.432,19$ & $192.544,52$ & $4,90 \%$ \\
\hline 2014 & 820 & 74 & 894 & $8,31 \%$ & $230.304,09$ & $11.158,00$ & $241.462,09$ & $4,65 \%$ \\
\hline 2015 & 998 & 93 & 1.091 & $8,52 \%$ & $260.949,57$ & $11.019,43$ & $271.969,00$ & $4,05 \%$ \\
\hline 2016 & 1.289 & 136 & 1.425 & $9,54 \%$ & $323.835,18$ & $14.914,63$ & $338.749,81$ & $4,40 \%$ \\
\hline 2017 & 1.596 & 181 & 1.777 & $10,19 \%$ & $429.194,80$ & $28.311,77$ & $457.506,57$ & $6,59 \%$ \\
\hline
\end{tabular}

Sumber: Pusat Data dan Statistik Reksadana Syariah (www.ojk.co.id).

Dilihat pada Tabel 1 bahwa reksadana konvensional lebih unggul dari reksadana syariah, disebabkan karena reksadana kovensional dikenal lebih dulu daripada reksadana syariah. Hal ini terlihat tahun 2012-2017 pada reksadana konvesional yang memiliki kenaikan tiap tahun yang lebih besar daripada reksadana syariah. Pada tahun 2017 dapat diketahui reksadana konvensional yang beredar sebesar 1.596 unit reksadana, sedangkan reksadana syariah yang beredar sebesar 181 unit reksadana. Perbedaan jumlah reksadana yang beredar sangat besar ini, membuktikan bahwa masyarakat masih lebih memilih untuk menginvestasikan dananya dengan produk dari reksadana konvensional. Pada kolom perbandingan NAB juga terlihat reksadana konvensional lebih unggul daripada reksadana syariah. Pada tahun 2017 dapat diketahui NAB reksadana konvensional sebesar Rp 429.194,80 Milyar sedangkan reksadana syariah sebesar Rp 28.311,77 Milyar. Lestari (2015) menjelaskan bahwa kondisi yang terlihat bahwa kinerja reksadana saham konvensional lebih baik daripada kinerja reksadana saham syariah, sehingga menunjukkan kinerja reksadana saham syariah mayoritas masih underperformed dibandingkan dengan reksadana konvensional dan pengujian kinerja reksadana syariah dengan pengujian kinerja reksadana konvensional belum secara luas diuji.

Penelitian kinerja Islamic dan Non-Islamic Index menunjukkan hasil yang beragam. Li et al (2016) yang menemukan bahwa di Malaysia, kinerja reksadana syariah lebih baik daripada kinerja Reksadana 
konvensional. Penelitian yang dilakukan oleh Iswanaji (2016) menemukan bahwa tidak terdapat perbedaan yang signifikan antara kinerja reksadana syariah dengan reksadana konvensional. Penelitian Qomariah et al (2016) menemukan perbedaan yang signifikan pada return reksadana konvensional dengan return reksadana syariah. Lianti et al (2017) menemukan bahwa antara kinerja reksadana saham syariah dan reksadana saham konvensional dalam metode Sharpe maupun metode Treynor tidak terdapat perbedaan signifikan. Sementara itu, Lestari (2015) menemukan perbedaan yang signifikan pada kinerja reksadana konvensional dengan kinerja reksadana syariah. Pengujian kinerja reksadana konvensional dengan reksadana syariah diperlukan untuk mencari tahu kinerja reksadana, tingkat risiko, dan perbedaan pada metode pengukuran kinerja reksadana syariah dibandingkan dengan reksadana konvensional di Indonesia.

\section{Reksadana}

Menurut undang-undang pasar modal no 8 tahun 1995, pasal 1 ayat 27 mendefinisikan Reksadana sebagai wadah yang digunakan untuk menghimpun dana dari masyarakat yang memiliki modal untuk diinvestasikan dalam portofolio efek oleh manajer investasi. Reksadana merupakan kepemilikan jenis saham dan berbagai jenis obligasi serta sekuritas lainnya, yang dimiliki oleh sekelompok pemodal dan dikelola oleh perusahaan investasi profesional karena akan membuat lebih kecil risiko yang dihadapi. Guna menciptakan kekuatan membeli yang kuat dibandingkan melakukan investasi sendiri, dana akan disatukan dari pemodal banyak pemodal (Sunariyah, 2004:224). Oleh karena itu, bagi masyarakat yang memiliki modal namun memiliki waktu yang terbatas dalam menghitung risiko, reksadana menjadi salah satu alternatif investasi tepat. Darmadji dan Fakhrudin (2011:166) menyatakan terdapat tiga hal yang terkait dengan reksadana:

1. Adanya dana dari masyarakat pemodal, baik individu maupun institusi.

2. Dana tersebut diinvestasikan ke dalam portofolio efek yang telah terdiversifikasi, dimana dana tersebut adalah dana milik bersama dan

3. Dana tersebut dikelola oleh manajer investasi.

Reksadana merupakan investasi alternatif atau investasi yang terdiversifikasi bagi para pemodal yang ingin berinvestasi dengan modal yang terbatas. Reksadana memiliki risiko kecil serta return yang baik, sehingga investasi reksadana memiliki banyak keuntungan bagi investor. Investasi reksadana dikelola oleh manajer investasi, oleh karena itupara investor tidak perlu memonitor aktivitas perdagangan di bursa setiap hari. Hal ini tentu memudahkan bagi investor yang tidak memiliki waktu untuk selalu melakukan pengecekan terhadap investasinya.

Reksadana sendiri saat ini telah berkembang dengan adanya reksadana syariah. Menurut Fatwa Dewan Syariah Nasional Majelis Ulama Indonesia (DSN-MUI) No. 80/DSN-MUI/II/2011 mendefinisikan reksadana yang beroperasi menurut ketentuan dan prinsip syariah islam baik dalam bentuk akad antara pemodal sebagian pemilik harta (shahib al-mal/ rabb al-mal) dengan manajer investasi sebagai wakil shahib al-mal, maupun antara manajer investasi sebagai wakil shahib al-mal dengan pengguna investasi. Dengan demikian, reksadana syariah memiliki kebijakan instrumennya yang berlandaskan prinsip-prinsip syariat islam, berupa akad, operasional sampai sistemnya sesuai dengan aturan syariat islam. Dana reksadana Syariah dalam Pengelolaannya tidak mengijinkan penggunaan strategi investasi yang mengarah ke strategi spekulasi. Dalam hal pembagian hasil keuntungan investasi syariah, antara para investor dan manajer investasi memberikan bagi hasil sesuai dengan proporsi modal yang dimiliki.

\section{Return Reksadana}

Return merupakan imbal hasil yang diperoleh ketika seseorang melakukan investasi. Oleh karena itu, meningkatkan return dalam berinvestasi merupakan hal penting yang harus diperhatikan oleh investor ketika melakukan investasi supaya dapat memperoleh keuntungan yang maksimal. Menurut Tandelilin (2010:186) menerangkan bahwa perlu dilakukan penghitungan secara akurat dalam memprediksi 
risk dan return yang dihasilkan oleh aset dalam melakukan investasi. Oleh karena itu, Qomariyah et al (2016) menemukan hasil bahwa terdapat perbedaan yang signifikan antara return reksadana saham konvensional dan return Reksadana saham syariah.

H1 : Terdapat perbedaan signifikan dalam return antara reksadana saham konvensional dengan reksadana saham syariah.

\section{Risiko Reksadana}

Dalam investasi, untuk mendapatkan return yang tinggi investor akan menghadapi risiko yang tinggi juga. Karena sudah menjadi hal yang seharusnya ketika kita mendapatkan return yang tinggi maka kita akan mendapatkan risiko yang tinggi pula (Hadi, 2013: 202). Hal tersebut bisa terjadi dalam reksadana konvesional maupun syariah. Tandelilin (2010:186) menerangkan bahwa perlu dilakukan penghitungan secara akurat dalam memprediksi risk dan return yang dihasilkan oleh aset dalam melakukan investasi. Penelitian Lestari (2015) menunjukkan bahwa antara reksadana syariah dengan reksadana konvensional baik dalam risiko, return dan dalam metode Sharpe terdapat perbedaan signifikan. Menurut Iswanaji (2016) menjelaskan bahwa tidak terdapat perbedaan signifikan antara risiko reksadana konvensional dengan reksadana syariah.

H2 : Terdapat perbedaan signifikan dalam risiko antara reksadana saham konvensional dengan reksadana saham syariah.

\section{Kinerja Reksadana}

Kinerja reksadana digunakan untuk mengukur perkembangan sebuah produk reksadana tersebut. Kinerja reksadana juga dapat digunakan untuk investor dalam hal pengambilan keputusan investasi dengan cara membandingkan kinerja satu reksadana dengan reksadana lainnya yang menjadi target investasinya. Dalam melihat atau menilai kinerja reksadana, investor juga perlu memperhatikan faktorfaktor lain seperti risiko, benchmark dan lainnya. Hal ini dilakukan supaya dapat mengetahui bagaimana kinerja sebuah reksadana, maka diperlukan cara untuk mengukur kinerja reksadana. Halim (2015:51) menyebutkan metode yang umum digunakan dalam menilai kinerja portofolio adalah metode Sharpe, metode Treynor dan metode Jensen.

Metode sharpe adalah sebuah metode yang umum digunakan untuk mengukur kinerja portofolio. Dalam mengukur kinerja reksadana menggunakan metode Sharpe, premi risiko portofolio (selisih rerata ringkat keuntungan portofolio dengan rerata suku bunga bebas risiko) dengan risiko portofolio yang dinyatakan dengan standar deviasi diperbandingkan (Halim, 2015:52). Lebih lanjut, Halim (2015:52) mengatakan bahwa semakin besar premi risiko terhadap standar deviasi maka dapat dikatakan bahwa kinerja tersebut semakin baik. Dengan kata lain, Semakin besar nilai metode Sharpe ini mengindikasikan bahwa semakin baik kinerja portofolio yang membentuk garis tersebut. Lestari (2015) menemukan perbedaan yang signifikan pada kinerja reksadana saham konvensional dengan reksadana syariah.

H3 : Terdapat perbedaan signifikan dilihat metode Sharpe antara reksadana konvensional dengan reksadana syariah.

Menurut Halim (2015:52) metode Treynor membandingkan antara premi risiko portofolio (selisih rerata tingkat keuntungan portofolio dengan rerata bunga bebas risiko) dengan risiko portofolio yang dinyatakan dengan beta (risiko pasar atau risiko sistematis). Formula ini menghitung tingkat kemiringan (slop) garis yang menghubungkan portofolio yang berisiko dengan bebas risiko (Halim, 2015:53). Dalam metode Treynor jika semakin besar tingkat kemiringan garis berarti semakin baik portofolio yang membentuk garis kemiringan (Halim, 2015:53). Hal ini menunjukkan bahwa semakin besar rasio premi risiko portofolio terhadap beta, maka dapat dikatakan bahwa kinerja portofolio semakin baik (Halim, 2015: 53). Metode Treynor relevan dipergunakan untuk investor yang memiliki berbagai portofolio atau menanamkan dananya pada berbagai reksadana atau melakukan diversifikasi pada berbagai portofolio, sehingga risiko portofolio dinyatakan dalam beta (Halim 2015:53). 
Mengenai teori penjelasan dari Halim (2015) bahwa penelitian Rahmah (2016) menjelaskan mengenai hasil perbandingan reksadana syariah dan reksadana konvensional dengan metode Sharpe, Treynor dan Jensen menunjukkan bahwa terjadi perbedaan signifikan.

H4 : Terdapat perbedaan signifikan dilihat metode Treynor antara reksadana konvensional dengan reksadana syariah.

Indek Jensen merupakan metode yang didasarkan pada konsep lini bursa sekuritas/keuangan (Security Market Line/SML) yang merupakan garis yang menghubungkan portofolio pasar dengan kesempatan investasi yang bebas risiko (Halim, 2015: 53). Lebih lanjut Halim, (2015: 53) mengatakan bahwa jika keuntungan aktual dari suatu portofolio lebih besar dari keuntungan yang sesuai dengan persamaan SML, maka metode Jensen akan positif dan sebaliknya, jika keuntungan aktual dari suatu portofolio lebih kecil dari keuntungan yang sesuai dengan persamaan SML, metode Jensen akan negatif .

Teori metode Jensen dari penjelasan diatas penelitian Jepryansyah et al (2014) menjelaskan bahwa adanya perbedaan yang signifikan antara reksadana syariah dengan reksadana konvensional. Sedangkan penelitian Pratiwi dan Putri (2017) menjelaskan tidak ada perbedaan signifikan antara reksadana syariah dengan reksadana konvensional. Berdasarkan uraian yang didukung oleh hasil penelitian di atas, maka hipotesis yang diajukan sebagai berikut:

H5 : Terdapat perbedaan signifikan dilihat metode Jensen antara reksadana saham konvensional dan reksadana saham syariah.

\section{METODE PENELITIAN}

Penelitian ini adalah penelitian deskriptif komparatif untuk membandingkan antara reksadana konvensional dengan reksadana syariah dalam hal return, risiko, dan kinerja yang dibagi kedalam 3 metode penilaian kinerja reksadana. Penelitian menggunakan data sekunder yang diperoleh dari Indonesian Stock Exchange (IDX) berupa data IHSG dan ISSI, Bank Indonesia (BI) berupa data data suku bunga Sertifikat Bank Indonesia (SBI) dan SBIS (Sertifikat Bank Indonesia Syariah) periode Januari 2012 sampai dengan Desember 2016, dan Pusat Data Kontan.co.id berupa data NAB reksadana saham konvensional maupun reksadana saham syariah periode akhir Desember 2014 - Desember 2017.

Populasi yang digunakan dalam penelitian adalah seluruh reksadana yang ada di Bursa Efek Indonesia yang berjumlah 1425 reksadana. Metode penentuan sampel penelitian dilakukan dengan cara purposive sampling dengan berdasarkan pada kriteria-kriteria yang terdiri dari: (1) Reksadana saham yang terdaftar di Bursa Efek Indonesia dan tidak pernah dilikuidasi selama periode penelitian yaitu bulan Januari 2012 sampai dengan bulan Desember 2017 dan (2) Reksadana saham tersebut memiliki data NAB setiap bulan yang lengkap sesuai penelitian yaitu bulan Januari 2012 sampai dengan bulan Desember 2017.

Penelitian ini akan menggunakan variabel rata-rata return reksadana, standar deviasi/risiko reksadana, metode Sharpe, metode Treynor dan metode Jensen. Variabel tersebut terbentuk dari pengukuran kinerja, melalui data Nilai Aktiva Bersih (NAB), IHSG/ISSI dan SBI/SBIS. Data dan pengukuran terlihat pada tabel 2. 
Tabel 2. Ringkasan Definisi Operasional

\begin{tabular}{|c|c|c|c|}
\hline No & Variabel & \multicolumn{2}{|r|}{ Pengukuran } \\
\hline 1 & $\begin{array}{l}\text { Return Reksa Dana } \\
\text { Saham }\end{array}$ & $\begin{array}{ll} & \\
\text { - } & \mathrm{Rp} \\
\text { - } & \mathrm{NABt} \\
\text { - } & \mathrm{NABt}-1\end{array}$ & $\begin{array}{l}\qquad \mathbf{R p}=\left(\mathrm{NAB}_{\mathrm{t}}-\mathrm{NAB}_{\mathrm{t}-1}\right) / \mathrm{NAB}_{\mathrm{t}-1} \\
=\text { Return reksadana. } \\
=\mathrm{NAB} \text { periode pengukuran } \mathrm{t} . \\
=\text { NAB periode pengukuran } t \text { sebelumnya. }\end{array}$ \\
\hline 2 & $\begin{array}{l}\text { Return pasar (IHSG } \\
\text { dan ISSI) }\end{array}$ & $\begin{array}{ll}\text { Keterangan : } \\
\text { - } \mathrm{Rm} \\
\text { - } & \text { IHSGt } \\
\text { - } & \text { IHSG }-1 \\
\end{array}$ & 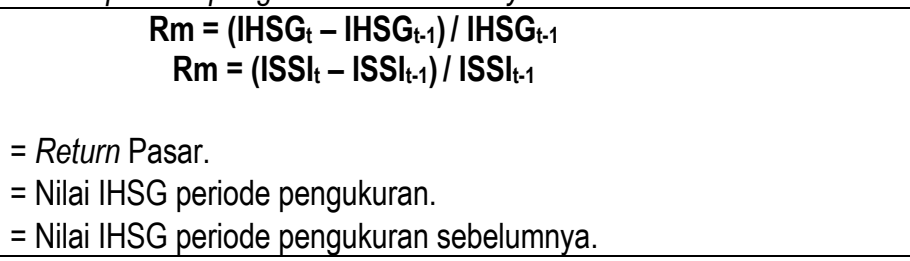 \\
\hline 3 & $\begin{array}{l}\text { Standar Deviasi Return } \\
\text { portofolio }\end{array}$ & $\begin{array}{ll}\text { Keterangan : } \\
\text { - } \sigma=\text { Sta } \\
\text { - } \quad \mathrm{Ri}=\text { Ret } \\
\text { - } \quad E=\text { Exp } \\
\text { - } \quad n=\text { jum }\end{array}$ & $\begin{array}{l}\qquad \sigma=\frac{\sqrt{\sum[R i-E(R i)]^{2}}}{n-1} \\
\text { dar Deviasi. } \\
\text { urn portofolio periode } t \text {. } \\
\text { ected return periode t. } \\
\text { lah data. }\end{array}$ \\
\hline 4 & Risk Free & $\begin{array}{ll}\text { Keterangan : } \\
\text { - } \quad \text { Total SBI } \\
-\quad \mathrm{N} \\
\end{array}$ & $\begin{array}{l}\qquad R f=\frac{\sum S B I}{N} \\
=\text { Sertifikat Bunga Indonesia (SBI/SBIS). } \\
=\text { Jumlah periode pengukuran. }\end{array}$ \\
\hline 5 & Beta $(\beta)$ & $\begin{array}{ll}\text { Keterangan: } \\
\text { - } \mathrm{Rp}=\text { Retc } \\
\text { - } \mathrm{Rm}=\text { Ret } \\
\text { - } \mathrm{a}=\text { Kons } \\
\text { - } \quad \beta=\text { Slop }\end{array}$ & $\begin{array}{l}\qquad \mathrm{Rp}=\alpha+\beta(\mathrm{Rm}) \\
\text { Irn reksadana. } \\
\text { urn pasar. } \\
\text { anta yang merupakan titik potong garis regresi dengan sumbu vertical. } \\
\text { e garis regresi. }\end{array}$ \\
\hline 6 & Metode Sharpe & $\begin{array}{l}\text { Keterangan : } \\
\text { - } \quad \text { Spi } \\
\text { - } \quad \text { Rpi } \\
\text { - } \quad \text { Rf } \\
\text { - } \quad \text { SDpi }\end{array}$ & $\begin{aligned} &$\[ \text { Spi }=\frac{R p i-R f}{S D p i} \]$ \\
= & \text { Metode Sharpe reksadana i pada waktu t. } \\
= & \text { Rata-rata return reksadana i pada waktu t. } \\
= & \text { Rata-rata atas tingkat bunga bebas risiko. } \\
= & \text { Standar deviasi dari return reksadana i pada waktu t. }\end{aligned}$ \\
\hline 7 & Metode Treynor & $\begin{array}{l}\text { Keterangan : } \\
\text { - } \quad \text { Tpi } \\
\text { - } \quad \text { Rpi } \\
\text { - } \quad \mathrm{Rf} \\
\text { - } \quad \text { Bpi }\end{array}$ & $\begin{array}{l}\qquad \text { Tpi }=\frac{R p i-R f}{\beta p i} \\
=\text { Metode Treynor reksadana i pada waktu t. } \\
=\text { Rata-rata return reksadana i pada waktu t. } \\
=\text { Rata-rata atas tingkat bunga bebas risiko. } \\
=\text { Beta reksadana i pada waktu t. }\end{array}$ \\
\hline 8 & Metode Jensen & $\begin{array}{ll}\text { Keterangan : } \\
\text { - } \quad \mathrm{Jpi} \\
\text { - } \mathrm{Rpi} \\
\text { - } \mathrm{Rf} \\
\text { - } \mathrm{Rm} \\
\text { - } \quad \mathrm{\beta pi} \\
\end{array}$ & $\begin{aligned} &$\[ J p i=(\text { Rpi - Rf) - } \beta \text { pi (Rm - Rf) } \]$ \\
= & \text { Metode Jensen rekasadana i pada waktu t. } \\
= & \text { Rata-rata return reksadana i pada waktu t. } \\
= & \text { Rata-rata ata tingkat bunga bebas risiko. } \\
= & \text { Rata-rata return pasar (IHSG). } \\
= & \text { Beta reksadana i pada waktu t. }\end{aligned}$ \\
\hline
\end{tabular}


Alat analisis penelitian ini menggunakan Paired sample t-test untuk membandingkan data dari dua sample yaitu Reksadana konvensional dan Reksadana syariah dalam variabel return, risiko, dan 3 metode kinerja (Sharpe, Treynor dan Jensen). Uji t-Paired adalah bagian dari statistik parametrik yang bertujuan untuk menentukan ada tidaknya perbedaan rata-rata dua sampel bebas, maka dua sampel yang dimaksud adalah sampel yang sama namun mempunyai dua data (Sujarweni, 2016:161). Uji ini digunakan untuk menguji beda dengan menggunakan rata-rata variabel data yang berdistribusi normal (Sujarweni, 2016:161). Dalam mengolah data akan menggunakan software SPSS 25.

\section{HASIL DAN PEMBAHASAN}

Berdasarkan kriteria, terdapat 12 (dua belas) produk reksadana saham yang diperjualbelikan dari manajer investasi yang berbeda sehingga terdiri dari 6 reksadana konvensional dan 6 reksadana syariah. Pemilihan produk reksadana didasarkan atas nilai NAB yang tinggi serta pengambilan jumlah produk yang sama agar tidak terjadi ketimpangan dalam melakukan penelitian perbandingan. Data dalam penelitian menggunakan periode tahun 2012-2017 terdiri dari 6 tahun.

\section{Statistik Deskriptif}

Berikut ini penjelasan mengenai deskriptif variabel yang digunakan dalam penelitian untuk melihat jumlah sampel (noun), nilai minimum (minimum) nilai maksimum (maximum) dan nilai rata-rata (mean) reksadana konvensional dan reksadana syariah pada tahun 2012-2017. Nilai rata-rata menujukkan rata-rata dalam satu variabel penelitian, diperoleh dengan menjumlahkan seluruh data dan membaginya dengan cacah data. Nilai maksimum menunjukkan nilai terbesar pada data. Nilai minimum menunjukkan nilai terkecil pada data. Berikut Tabel 3. yang menunjukkan statistik deskriptif reksadana konvensional dan syariah:

Tabel 3. Hasil Statistik Diskriptif

\begin{tabular}{|c|c|c|c|c|c|c|c|c|}
\hline \multirow{2}{*}{$\begin{array}{c}\text { Kinerja } \\
\text { Reksadana }\end{array}$} & \multicolumn{2}{|c|}{ N } & \multicolumn{2}{c|}{ Minimum } & \multicolumn{2}{c|}{ Maximum } & \multicolumn{2}{c|}{ Mean } \\
\cline { 2 - 9 } & Konvensional & Syariah & Konvensional & Syariah & Konvensional & Syariah & Konvensional & Syariah \\
\hline Return & 36 & 36 & $-0,0113$ & $-0,0267$ & 0,0253 & 0,0222 & 0,0068 & 0,0042 \\
\hline Risiko & 36 & 36 & 0,0134 & 0,0141 & 0,0765 & 0,0589 & 0,0392 & 0,0371 \\
\hline Sharpe & 36 & 36 & $-3,4154$ & $-2,9375$ & $-0,5417$ & $-0,5490$ & $-1,5947$ & $-1,6427$ \\
\hline Treynor & 36 & 36 & $-0,0949$ & $-0,0800$ & $-0,0227$ & $-0,0226$ & $-0,0547$ & $-0,0515$ \\
\hline Jensen & 36 & 36 & $-0,0279$ & $-0,0231$ & 0,0313 & 0,0211 & 0,0023 & 0,0055 \\
\hline
\end{tabular}

Sumber: data diolah, 2018

Hasil Statistik deskriptif Tabel 3. dapat dijelaskan sebagai berikut:

1. Pada return reksadana dapat dilihat nilai minimum konvensional sebesar $-0,0113$ dan syariah sebesar -0,0267, hal ini mengindikasikan kinerja terendah dialami oleh reksadana syariah. . Dilihat dari nilai maximum pada reksadana konvensional sebesar 0,0253 dan reksadana syariah sebesar 0,0222 menunjukkan bahwa return tertinggi diraih oleh reksadana konvensional. Nilai mean return reksadana saham konvensional lebih tinggi $(0,0068)$ dibandingkan reksadana saham syariah $(0,0042)$. Hal ini mengindikasikan bahwa return reksadana konvensional lebih baik dibandingkan dengan reksadana syariah.

2. Pada risiko reksadana dapat dilihat nilai minimum konvensional sebesar 0,0134 dan syariah sebesar 0,0141 , hal ini mengindikasikan bahwa risiko terendah terjadi pada reksadana konvensional. Nilai maximum pada reksadana konvensional sebesar 0,0765 dan reksadana syariah sebesar 0,0589, hal ini menunjukkan bahwa risiko tertinggi dimiliki oleh reksadana konvensional. Nilai mean risiko reksadana saham konvensional $(0,0392)$ lebih tinggi dibandingkan reksadana saham syariah 
$(0,0371)$. Hasil risiko mendindikasikan bahwa risikko reksadana konvensional lebih tinggi dibandingkan dengan risiko reksadana syariah.

3. Pada kinerja reksadana dengan metode Sharpe dapat dilihat nilai minimum konvensional sebesar 3,415 dan syariah sebesar $-2,938$, hal ini menunjukkan menurut pengukuran metode Sharpe kinerja terendah terjadi pada reksadana konvensional. Nilai maximum pada reksadana konvensional sebesar $-0,5417$ dan reksadana syariah sebesar $-0,5490$, hal ini menunjukkan bahwa menurut metode Sharpe kinerja tertinggi terjadi pada reksadana konvensional. Nilai mean metode Sharpe reksadana saham konvensional $(-1,5947)$ lebih besar dibandingkan reksadana saham syariah(1,6429). Hasil mean menunjukkan bahwa kinerja kedua reksadana tidak baik dan kinerja reksadana syariah lebih buruk dibandingkan dengan kinerja reksadana konvensional.

4. Pada kinerja reksadana dengan metode Treynor dapat dilihat nilai minimum konvensional sebesar 0,0949 dan syariah sebesar $-0,0800$. Nilai maximum pada reksadana konvensional sebesar $-0,0227$ dan reksadana syariah sebesar $-0,0226$. Hal ini menunjukkan bahwa nilai dari risk free lebih besar dari pada return yang didapatkan pada kedua reksadana dengan nilai tidak jauh berbeda. Nilai mean return reksadana konvensional lebih rendah (sebesar -0,054737) dibandingkan reksadana syariah $(-0,051502)$. Hasil mean tersebut dapat diketahui reksadana saham syariah memiliki kinerja lebih baik daripada reksadana saham konvensional.

5. Pada kinerja reksadana dengan metode Jensen dapat dilihat nilai minimum konvensional sebesar 0,0279 dan syariah sebesar $-0,0231$, hal ini menunjukkan bahwa menurut metode Jensen kinerja terendah terjadi pada reksadana konvensional. Nilai maximum pada reksadana konvensional sebesar 0,0313 dan reksadana syariah sebesar 0,0211. Hal ini menunjukkan bahwa kinerja pada metode Jensen tertinggi terjadi pada reksadana konvensional. Nilai mean return reksadana konvensional terlihat lebih rendah (sebesar 0,0023$)$ dibandingkan reksadana syariah $(0,0055)$. Hasil ini menunjukkan bahwa kinerja reksadana syariah lebih baik kinerjanya dibandingkan dengan reksadana konvenional berdasarkan metode Jensen.

Hasil uji normalitas yang telah dilakukan ditunjukkan pada Tabel 4. sebagai berikut:

Tabel 4. Hasil Uji Normalitas

\begin{tabular}{|c|c|c|c|c|c|}
\hline \multirow{2}{*}{$\begin{array}{c}\text { Kinerja } \\
\text { Reksadana }\end{array}$} & \multicolumn{2}{|c|}{ Signifikansi } & \multirow{2}{*}{$\begin{array}{c}\text { Alpha } \\
(\boldsymbol{\alpha})\end{array}$} & \multicolumn{2}{|c|}{ Keterangan } \\
\cline { 2 - 3 } \cline { 6 - 6 } & Konvensional & Syariah & & Konvensional & Syariah \\
\hline Return & 0,13 & 0,196 & & Normal & Normal \\
\hline Risiko & 0,099 & 0,2 & \multirow{4}{*}{0,05} & Normal & Normal \\
\cline { 3 - 3 } \cline { 6 - 6 }$n$ & 0,2 & 0,093 & Normal & Normal \\
\hline Indeks Sharpe & 0,2 & 0,2 & & Normal & Normal \\
\hline Indeks Treynor & 0,23 & 0,2 & & Normal & Normal \\
\hline Indeks Jensen & 0,123 & & &
\end{tabular}

Sumber: data diolah, 2018

Berdasarkan hasil pengujian Kolmogorov-Smirnov dengan menggunakan program SPSS 25 untuk membuktikan keduanya berdistribusi normal atau tidak dan untuk menentukan langkah pengujian perbandingan selanjutnya. Pada Tabel 4 menunjukkan bahwa nilai signifikansi tiap variabel lebih dari 0,05 . Hasil tersebut menunjukkan bahwa data berdistribusi normal baik reksadana konvensional maupun syariah. Dengan demikian untuk langkah selanjutnya dilakukan perbandingan menggunakan Paired sample t-test.

Hasil Uji Paired sample T-Test antara reksadana konvensional dengan reksadana syariah ditunjukkan pada Tabel 5. 
Tabel 5. Hasil Paired Sample T-test Kinerja Reksadana dalam Return

\begin{tabular}{|c|c|c|c|}
\hline Variabel & Signifikansi & Uji Hipotesis & Keterangan \\
\hline Return & 0,014 & $\mathrm{H}_{1}$ Diterima & Ada Perbedaan \\
\hline Risiko & 0,230 & $\mathrm{H}_{2}$ Ditolak & Tidak Ada Perbedaan \\
\hline Metode Sharpe & 0,485 & $\mathrm{H}_{3}$ Ditolak & Tidak Ada Perbedaan \\
\hline Metode Treynor & 0,404 & $\mathrm{H}_{4}$ Ditolak & Tidak Ada Perbedaan \\
\hline Metode Jensen & 0,288 & $\mathrm{H}_{5}$ Ditolak & Tidak Ada Perbedaan \\
\hline
\end{tabular}

Sumber: data diolah, 2018

Berdasarkan tabel 5. menunjukkan bahwa hipotesis 1 diterima, terlihat dari nilai signifikansi variabel return sebesar 0,014 lebih rendah dari 0,05. Di sisi lain untuk hipotesis 2,3,4, dan 5 ditolak yang terlihat dari nilai signifikansi variabel risiko $(0,230)$, Metode Sharpe $(0,485)$, metode Treynor $(0,404)$ dan metode Jensen $(0,288)$ lebih rendah dari 0,05.

\section{Return Reksadana Konvensional dan Reksadana Syariah}

Berdasarkan hasil analisis data terhadap variabel return, diperoleh tingkat signifikansi sebesar 0,014 , karena nilai signifikansi lebih kecil dari $0,05(0,014<0,05)$, maka H1 diterima. Hal ini mengindikasikan bahwa return reksadana konvensional dan reksadana syariah memiliki perbedaan yang signifikan. Penelitian ini menemukan bahwa return reksadana konvensional lebih besar dibandingkan dengan reksadana syariah yang terlihat pada nilai return reksadana konvensional sebesar 0,0068 dan reksadana syariah sebesar 0,0042 . Hal ini disebabkan karena nilai NAB reksadana yang sering berubah-ubah setiap waktu tergantung dengan nilai instrumen portofolio yang ada di dalam masing-masing produk (Manurung, 2007:5). Selain hal tersebut, produk reksadana konvensional yang dikenal lebih dahulu oleh masyarakat, memiliki banyak jenis pilihan produk yang dijualbelikan daripada reksadana syariah dan tidak melalui proses cleansing, maka hal tersebut yang membuat return tinggi. Sebaliknya untuk reksadana syariah hanya memperjualbelikan produknya sesuai dengan ketentuan syariat Islam. Menurut Huda dan Nasution (2008) dalam reksadana syariah return yang didapatkan melalui proses Cleansing, Filterisasi dan kegiatan haram. Berdasarkan hal itu, produk reksadana syariah yang dijualbelikan mengakibatkan tidak mampu meningkatkan fluktuasi dari penjualan itu sendiri, maka reksadana syariah dikatakan kurang marketable (Putriana, 2016). Pendapat ini, sejalan dengan penelitian Lestari (2015) dimana return mengalami perbedaan secara signifikansi antara kinerja reksadana syariah dan reksadana konvensional dengan return reksadana saham, menjelaskan bahwa reksadana konvensional memberikan return yang unggul dibandingkan reksadana syariah. Hal tersebut disebabkan karena adanya prinsip pokok yang membedakan reksadana syariah dalam mengelola portofolio investasinya, sehingga menjadi berbeda dari reksadana konvensional. Namun, Qomariah et al (2016) menjelaskan bahwa reksadana syariah lebih unggul daripada reksadana konvensional. Dikarenakan strategi manajer investasi reksadana melakukan rotasi pada sektor saham yang potensial.

\section{Risiko Reksadana Konvensional dan Reksadana Syariah}

Berdasarkan hasil analisis data terhadap variabel risiko, diperoleh tingkat signifikansi sebesar 0,230 , karena nilai signifikansi lebih besar dari $0,05(0,230>0,05)$, maka $\mathrm{H} 2$ ditolak. Hal ini menunjukkan bahwa risiko reksadana konvensional dan reksadana syariah memiliki tidak ada perbedaan. Hal disebabkan karena keduanya merupakan jenis investasi yang sama yaitu reksadana dan memiliki tata cara pengelolaan yang sama yaitu sama-sama melalui manajer investasi. Untuk produk reksadana konvensional, disebabkan karena prinsip dalam investasi high risk high return, yang artinya tingkat pengembalian reksadana konvensional yang tinggi akan membuat risiko juga tinggi. Seperti halnya dalam buku Jogiyanto (2014:30) bahwa return dan risiko mempunyai hubungan yang positif, karena semakin besar risiko yang ditanggung, maka semakin besar pula return yang diharapkan. Tidak adanya perbedaan didalam 
risiko, dapat dilihat perbedaan reksadana dalam bentuk operasionalnya, yang mana reksadana konvensional tanpa proses screening, hal ini menyebabkan banyaknya saham yang dimasukkan kedalam produk reksadana untuk menciptakan produk yang memiliki return tinggi, dengan begitu risiko menjadi tinggi. Sedangkan untuk reksadana syariah dalam operasionalnya memiliki proses screaning, adanya proses tersebut membuat reksadana syariah berisiko karena portofolio yang terbentuk dalam reksadana syariah menyebabkan manajer investasi membentuk portofolio dengan diversifikasi rendah, dan mempengaruhi return. Risiko reksadana konvensional sebesar 0,0392 dan reksadana syariah sebesar 0,0371, menunjukkan bahwa nilai risiko antara reksadana konvesional lebih besar daripada reksadana syariah.

Hasil ini sejalan dengan penelitian Iswanaji (2016) bahwa risiko tidak mengalami perbadaan signifikan. Tidak adanya perbedaan yang signifikan, merupakan salah satu bukti perkembangan ekonomi syariah di Indonesia, khususnya di pasar modal dan merupakan prestasi yang menggembirakan terhadap ekonomi syariah. Bertentangan dengan hasil penelitian Lestari (2015) menunjukkan bahwa risiko mengalami perbedaan secara signifikan antara reksadana syariah dan reksadana konvensional, serta risiko konvensional lebih unggul daripada reksadana syariah.

\section{Metode Sharpe antara Reksadana Konvensional dan Reksadana Syariah}

Hasil analisis data terhadap variabel metode Sharpe, diperoleh tingkat signifikansi sebesar 0,485, karena nilai signifikansi lebih besar dari 0,05 $(0,485>0,05)$, maka H3 ditolak. Hal ini mengindikasikan bahwa kinerja reksadana konvensional dan syariah menggunakan metode Sharpe tidak terdapat perbedaan yang signifikan. Nilai rata-rata Sharpe reksadana konvensional sebesar $-1,6427$ dan reksadana syariah sebesar $-1,594$. Nilai tersebut menunjukkan bahwa kinerja reksadana baik yang konvensional maupun syariah memiliki kinerja yang kurang baik. Kurang baiknya kinerja reksadana disebabkan karena nilai dari risk free yang lebih besar dibandingkan dengan return reksadana. Risk free dengan return reksadana ini melihat anatara return reksadana syariah yang lebih kecil dibandingkan dengan SBIS dan reksadana konvensional yang lebih kecil dibandingkan dengan SBI.

Hasil ini sejalan dengan penilitian Lianti et al (2017), Pratiwi dan Putri (2017) dan Jeprayansyah dan Fauzie (2014). Bahwa metode Sharpe tidak mengalami perbedaan secara signifikan antara reksadana syariah dan konvensional. Jeprayansah dan Fauzie (2014) selain menyatakan tidak ada perbedaan secara signifikan, menyatakan bahwa hasil Sharpe syariah lebih unggul dari konvensional. Penelitian Lianti et al (2017) menyatakan bahwa kinerja dengan metode Sharpe menunjukkan reksadana konvensional lebih unggul dari reksadana syariah. Bertentangan dengan penelitian Lestari (2015), yang menyatakan bahwa metode Sharpe mengalami perbedaan secara signifikan antara reksadana syariah dan konvensional.

\section{Metode Treynorantara Reksadana Konvensional dan Reksadana Syariah}

Hasil analisis data terhadap variabel metode Treynor, diperoleh tingkat signifikansi sebesar 0,404, karena nilai signifikansi lebih besar dari 0,05 $(0,404>0,05)$, maka H4 ditolak. Hal ini mengindikasikan bahwa tidak terdapat perbedaan terdapat kinerja reksadana konvensional dan syariah menggunakan metode Treynor. Nilai rata2 kinerja reksadana menggunakan metode Treynor menunjukkan bahwa nilai rata-rata reksadana konvensional sebesar -0,0547 dan reksadana syariah sebesar 0,0515 . Nilai tersebut menunjukkan bahwa kinerja reksadana baik yang konvensional maupun syariah memiliki kinerja yang kurang baik. Hal ini disebabkan oleh adanya nilai risk free rate lebih baik daripada nilai dari reksadana saham. Nilai risk free rate yang lebih tinggi mengindikasikan bahwa investasi pada reksadana kurang menguntungkan dibandingkan dengan investasi lain.

Hasil ini sejalan dengan penelitian serta Jepryansyah (2014) menyatakan bahwa tidak ada perbedaan signifikan dan kinerja syariah lebih baik dari konvensional. Selain penelitian itu, Lianti et al (2017) menjelaskan bahwa kinerja konvensional lebih baik dari kinerja syariah dalam bentuk Treynor dan tidak ada perbedaan secara signifikan antara reksadana konvensional dan reksadana syariah. Pratiwi dan Putri 
(2017), menjelaskan bahwa tidak ada perbedaan secara signifikan antara reksadana konvensional dan reksadana syariah. Bertentangan dengan penelitian Rahmah (2016), dimana dengan metode Treynor mengalami perbedaan secara signifikan antara reksadana konvensional dan reksadana syariah.

\section{Metode Jensen antara Reksadana Konvensional dan Reksadana Syariah}

Hasil analisis data terhadap variabel metode Jensen, diperoleh tingkat signifikansi sebesar 0,288 , karena nilai signifikansi lebih besar dari 0,05 $(0,288>0,05)$, maka H5 ditolak. Hal ini mengindikasikan bahwa antara kinerja reksadana konvensional dan syariah menggunakan metode Jensen tidak terdapat perbedaan yang signifikan. Nilai rata2 kinerja reksadana menggunakan metode Jensen menunjukkan bahwa reksadana konvensional sebesar 0,0023 dan reksadana syariah sebesar 0,00155. Nilai kinerja dengan metode Jensen tersebut menunjukkan bahwa reksadana saham baik secara konvensional maupun syariah, sama-sama menghasilkan kinerja yang baik, dan menunjukkan bahwa Manajer Investasi mampu memberikan kinerja di atas kinerja pasar sesuai risiko yang dimiliki.

Hasil ini sejalan dengan penelitian Pratiwi dan Putri (2017), bahwa tidak terdapat berbedaan secara signifikan dengan menggunakan metode Jensen dan hasil rata-rata, menunjukkan bahwa reksadana konvensional lebih unggul dari reksadana syariah. Bertentangan dengan penelitian Jeprayansyah dan Fauzie (2014), dimana kinerja dengan metode Jensen memiliki perbedaan secara signifikan antara reksadana konvensional dan reksadana syariah.

\section{PENUTUP}

Penelitian ini membandingkan return, risiko dan kinerja antara reksadana syariah dengan konvensional. Temuan Penelitian ini menghasilkan kesimpulan bahwa (1) return antara reksadana konvensional dengan syariah memiliki perbedaan yang signifikan dengan return reksadana konvensional lebih besar dibandingkan dengan reksadana syariah, (2) tidak ada perbedaan risiko dan kinerja (Metode Sharpe, Treynor dan Jensen) antara reksadana konvensional dengan reksadana syariah, yang berarti bahwa risiko dan kinerja antara reksadana konvensional dengan reksadana syariah tidak memiliki perbedaan yang berarti. Oleh karena itu investor maupun investor yang hendak berinvestasi dapat tenang memilih akan berinvestasi pada reksadana konvensional maupun syariah karena tidak ada perbedaan dalam hal risiko dan kinerja reksadananya. Pilihan dalam berinvestasi dapat kembali pada kecenderungan investor apakah menekankan pada return atau pada syariat islam

Penelitian selanjutnya diharapkan meneliti dengan baik itu variabel lain maupun dengan reksadana jenis yang lain seperti reksadana pendapatan (Qomariyah et al, dan pertumbuhan AUM (Lailiyah et al 2016). selain itu, diharapkan juga dapat menggunakan uji yang lain seperti uji independent sampel t-test (Iswanaji, 2016); (Lestari, 2015) dan (Lianti et al 2017) dan uji mann-whitney-u (Putra dan Fauzie, 2014).

\section{DAFTAR PUSTAKA}

Darmadji, Tjiptono dan Hendy M. Fakhruddin. 2001. Pasar Modal di Indonesia. Jakarta: Salemba Empat.

Fatwa DSN-MUI No. 80/DSN- MUI/III/2011 tentang Penerapan Prinsip Syariah dalam Mekanisme Perdagangan Efek Bersifat Ekuitas di Pasar Reguler Bursa Efek.

Hadi, Nur. 2013. Pasar Modal: Acuan Teoretis dan Praktis Investasi di Instrument Keuangan Pasar Modal. Yogyakarta: Graha IImu.

Halim, Abdul. 2015. Analisis Investasi dan Aplikasinya: Dalam Aset Keuangan dan Aset Riil. Jakarta: Salemba Empat.

Huda, Nurul dan Mustofa Edwin Nasution. 2008. Investasi Pada Pasar Modal Syariah. Jakarta: Kencana Prenada Media Group. 
Iswanaji, Chaidir. 2016. "Perbandingan Kinerja Reksadana Syariah dan Kinerja Reksadana Konvensional Ditinjau Berdasarkan Tingkat Risk dan Return". Jurnal Media Ekonomi dan Manajemen. Volume 31, Nomor 2, ISSN: 2503-4460, Juli 2016. Magelang.

Jogiyanto, Hartono. 2014. Teori dan Praktik Portofolio dengan Excel. Jakarta: Salemba Empat.

Lailiyah et al. 2016. "Analisis Perbandingan Kinerja Reksadana Syariah Dan Reksadana Konvensional (Studi pada Reksadana yang Terdaftar di Otoritas Jasa Keuangan Periode 2012-2016)". Jurnal Administrasi Bisnis (JAB). Volume 35, Nomor 2, Juni 2016. Malang.

Lestari, Winda Rika. 2015. "Kinerja Reksadana Saham Syariah dan Reksadana Saham Konvensional". Jurnal Magister Manajemen, Volume 01, Nomor 01, Januari 2015. Lampung.

Lianti et al. 2017. "Analisis Perbandingan Kinerja Reksadana Saham Syariah Dengan Reksadana Saham Konvensional". Jurnal Ekonomi dan Bisnis. Volume 18, Nomor 2, ISSN: 2549-5003, Agustus 2017. Lhokseumawe.

Li et al. 2016. "Islamic or conventional mutual funds: Who has the upper hand? Evidence from Malaysia". Pacific-Basin Finance Journal. Januari 2016. Malaysia.

Manurung, A. Haymans. 2010. Panduan Sukses Menjual Reksadana. Jakarta: PT Gramedia Widiasarana Indonesia.

Pratiwi, Nila dan Siska Yunila Putri. 2017. "Analisis Perbandingan Kinerja Reksadana Saham Syariah dengan Reksadana Konvensional (Reksadana yang Terdaftar di OJK Periode 2013-2015)". Journal of Economic Studies. Volume 1, Nomor 1, Januari-Juli. Padang.

Putra, Jepryansyah dan Syarief Fauzie. 2014. "Analisis Perbandingan Kinerja Reksa Dana Konvensional dengan Reksa Dana Syariah di Indonesia". Jurnal Ekonomi dan Keuangan. Volume 2, Nomor 5.

Qomariyah et al. 2016. "Perbandingan Kinerja Reksadana Syariah dan Reksadana Konvensional (pada Reksadana Saham dan Reksadana Pendapatan Tetap yang terdaftar di BEI Periode 20102014)". Jurnal Keuangan dan Perbankan. Volume 20, Nomor 03, September 2016. Jember.

Rahmah, Azizatur. 2016. "Analisis Perbandingan Kinerja Reksadana Syariah dan Kinerja Reksadana Konvensional dengan Metode Sharpe, Treynor dan Jensen". Analytical Islamic. Volume 5, Nomor 1, 2016:20-40. Sumatera.

Sujarweni, V. Wiratna. 2016. Kupas Tuntas Penelitian Akuntansi dengan SPSS. Yogyakarta: Pustaka Baru Press.

Sunariyah. 2004. Pengantar Pengetahuan Pasar Modal. Yogyakarta: UPP-AMP YKPN.

Syafrida et al. 2014. "Perbandingan Kinerja Instrumen Investasi Berbasis Syariah dengan Konvensional pada Pasar Modal di Indonesia". Jurnal Al-Iqtishad. Volume 6, Nomor 2, April 2014. Jakarta.

Tandelilin, Eduardus. 2010. Analisis Investasi dan Manajemen Portofolio. Yogyakarta. PT. BPFE.

Tim Uang dan Efek. 1997. Mengapa Harus Reksadana?, Jakarta: Majalah Uang dan Efek, Glory Offset dan Press.

Undang - Undang Pasar Modal No.8 Tahun 1995. 1996. Himpunan Peraturan Pasar Modal. Jakarta: Sinar Grafika.

Winarno, Wing Wahyu. 2017. Analisis Ekonometrika dan Statistika dengan Eviews. Yogyakarta: UPP STIM YKPN.

http://www.ojk.go.id. Diakses September 2017. 